\title{
Interpersonal Skills' Analysis of Students in Physical Education Subjects in the Pandemic Situation
}

\author{
$1^{\text {st }}$ Gomang Genurianto \\ Departement Sport Science \\ Universitas Negeri Yogyakarta \\ Yogyakarta, Indonesia \\ gomanggenurianto.2019@student.uny.ac.id
}

\author{
$2^{\text {nd }}$ Rachmah Laksmi Ambardini \\ Departement Sport Science \\ Universitas Negeri Yogyakarta \\ Yogyakarta, Indonesia \\ rachmah_la@uny.ac.id
}

\author{
$3^{\text {rd }}$ Suharjana \\ Departement Sport Science \\ Universitas Negeri Yogyakarta \\ Yogyakarta, Indonesia \\ suharjana_pkr@uny.ac.id
}

\begin{abstract}
This study aimed to describe the interpersonal skills of students in learning physical education in grade IX of SMP Budi Utama Sleman in semester I of the 2020/2021 academic year during the pandemic. The population in this study were all students of grade IX. The sampling in this study was drawn by using proportional random sampling technique and it was found that there were 43 students who were sampled. The data collection techniques used in this study were questionnaires and interviews. Quantitative and qualitative methods were chosen as data analysis techniques in this study. The results showed that the interpersonal skills of class IX students in Physical Education subjects during the pandemic was in the medium category, which proved to be $58 \%$ of students' interaction skills, $\mathbf{6 9 . 8 \%}$ of students' communication skills, $\mathbf{5 6 . 2 \%}$ of students' cooperation skills, and students' empathy $70.5 \%$. Suggestions from researchers for educators are to design learning that focuses not only on knowledge and skill factors, but also on increasing interpersonal skills of students, because interpersonal skills is a determining factor for one's success.
\end{abstract}

Keywords-Interpersonal Skills, Physical Education.

\section{INTRODUCTION}

In this time the world is being tested a big enough problem. This problem is the covid-19 outbreak. When the Covid-19 outbreak emerged, all human activities were restricted. Including learning activities at the primary school level to lecture level that implements learning from home. This is done to limit the massive spread of the virus. The study from home policy began to be implemented on March 92020 after the minister of education and culture issued circular numbers 2 of 2020 and 3 of 2020 concerning online learning and working from home to prevent the spread of Corona Virus Disease (Covid-19). All leaders of educational institutions in each region were asked to stop their academic activities such as face-to-face learning. As a follow-up to this circular, all educational institutions are also asked to issue policies regarding the online learning process for students and students. Therefore all educational institutions in Indonesia are making adjustments to this policy by changing all teaching and learning activities to be carried out online.

The learning system in a network is a learning system without face to face directly between teachers and students but is carried out online using the internet network [1]. The learning itself is a process used by the teacher to help students achieve their learning goals [2]. Learning can also be interpreted as a conscious effort to stimulate learning by organizing deliberate experiences to help students achieve the desired changes. [3]. The use of information technology in online learning during the Covid-19 pandemic was considered effective by students in terms of understanding the material, but there are still some obstacles including the physical benefits of physical learning, and the types of tasks given to students are monotonous. [4]. Many schools employ online assignment methods for students. The assignment was carried out through various available social media, especially whatsapp groups. In an emergency situation because of the corona virus like now, a form of assignment that is seen as effective in distance learning. As a consequence, the introduction of the concept of a lesson as applied in face-to-face learning does not work well. In face-to-face learning, there will be the delivery of learning concepts and objectives first. Then learning continues until its understanding and development. These stages are considered not going well in an emergency situation like now [5].

Teachers must ensure the teacing and learning activities still continue even though students are at home, this is so that the goals of national education can still be achieved. Existing intelligence can be used as the main guide for educators so that they can determine learning objectives more precisely and be able to make learning more enjoyable for students. So that the fun learning process will be seen in the final result. Their intelligence is also able to solve problems so that they can adapt to existing situations. In fact, the practice of education in Indonesia tight now only provides a portion of the ability of knowledge and skills, it can even be said to be more oriented towards hard skills abilities. This means that students are only given academic expertise and technical competence, for example, students are only given skills to solve problems related to physical education. If you look at the reality in learning carried out at school, related to providing physical education subject matter, sports and health, teachers tend to prefer to quickly complete the material being taught, without paying attention to a proportional increase in student creativity, student hard work attitudes, less giving students freedom to express new ideas, and communicate between friends in the group in solving a problem [6].

One of the goals of national education is to develop intelligence. Intelligence is the ability to learn so as to gain knowledge so that it is able to carry out real actions that have 
goals and a rational way of thinking [7]. A person's intelligence includes the following elements: a) logical-mathematical intelligence, b) language intelligence, c) musical intelligence, d) spatial-visual intelligence, e) kinesthetic intelligence, f) interpersonal ability, g) intrapersonal intelligence, and $\mathrm{h}$ ) naturalist intelligence [8]. One of the abilities that are often used in teaching and learning activities is interpersonal skills. Interpersonal skills are skills that are used every day when communicating and interacting with other people, both individually and in groups [9]. Interpersonal skills can also be interpreted as the abilities a person needs and uses to communicate and interact with other people.

The Covid-19 pandemic has had a devastating impact on education including, learning disruption, and decreased access to education and research facilities, job loss and increased student dependencies [10]. In learning during a pandemic, of course, the quality of this ability is far different from normal conditions. It can be seen from the habits of students during normal learning that no longer occurs during learning in this pandemic situation, for example: direct discussion, debate about case studies, playing, chatting and others. There are still many habits that are difficult to find and aplly during a pandemic. This is a concern for educators about the development of the interpersonal skills of students that have decreased during a pandemic like now.

Interpersonal ability is a person's ability to be sensitive to other people's feelings [7]. Interpersonal skills are the ability to understand and cooperate with others [11]. Interpersonal intelligence is the ability to distinguish and provide perceptions about other people's motivations, moods, and feelings with the ability to respond effectively [12]. This statement intends to explain that interpersonal skills are optimal self-mastery abilities and self-actualization abilities in responding to the conditions of others. Children with more abilities in this skill tend to understand and interact with other people so that they are easier to socialize with their environment. This intelligence is also called social intelligence. Children with social intelligence, are not only able to make close friendships with their friends easily, and also have high abilities in leading, organizing, handling disputes between friends, gaining sympathy from other children and so on. Interpersonal skills function very effectively in an educational context [13].

Interpersonal skills are divided into three, including selfregard, emotional self-awareness, assertiveness, and selfactualization. [14]. Interpersonal skills include 6 aspects, including communication skills, emotional intelligence, team working, negotiation persuation and influencing skills, conflict resolution and meditation, and the other are problem solving and decision making [9]. Interpersonal skills have 2 social scopes, the first is social awareness which includes awareness of politics, the ability to develop others, take advantage of diversity, service orientation and empathy, the second is social skills which include managerial skills, the ability to influence others, the ability to communicate well, conflict management, working together, and synergizing [15]. Interpersonal skills are thought to involve a complex mix of psychological factors that involve a combination of affective components, skillful, and cognitive components, for example social perception is a form of situation-specific cognition that involves processes such as attention, reasoning, social intelligence or knowledge of social habits and expectations, and problem solving. [13]. The ideal competencies that exist in interpersonal skills include the ability to communicate, empathize, sympathize, work together, guide and motivate [16]. The taxonomy of interpersonal abilities divides this ability into 12 components. These components include a) Active Listening, b) Oral Communication, c) Written Communication, d) Assertive Communication, e) Nonverbal Communication, f) Cooperation \& Coordination, g) Trust, h) Intercultural Sensitivity, i) Service Orientation, j) Self-presentation, k) Social Influence and 1) Conflict Resolution \& Negotiation [17].

The first six components of the explanation are that Active listening can be interpreted as paying attention to what is being said, asking the other party to explain exactly what he means, and asking that ambiguous ideas or statements be repeated. Oral Communication can be interpreted as sending verbal messages constructively. Written communication means writing clearly and precisely. Assertive communication means that writing clearly and precisely or written clearly and precisely. Assertion communication directly expresses a person's feelings, preferences, needs and opinions in a way that does not threaten or punish others. Nonverbal communication is the ability to strengthen or replace spoken communication through the use of body language, gestures, sounds, or artifacts. Cooperation and coordination are understanding and working with other people in a group or team including offering assistance to those in need and setting the pace of activities to suit the team's needs [17]

The next six components of interpersonal skills are Trust which means individual belief in the integrity or reliability of other people or objects; the willingness of one party to be vulnerable to actions of the other is based on the expectation that certain actions that are important to the trustor will be taken. Intercultural sensitivity is Respecting individual differences among people. Service orientation is a set of basic individual tendencies and tendencies to provide services, be polite and assist in dealing with customers, clients and colleagues. Self-presentation is a process in which individuals seek to influence the reactions and images people have of them and their ideas of managing these impressions include a wide variety of behaviors designed to create a positive influence on co-workers. Social influence is guiding people to adopt certain behaviors, beliefs or attitudes; influence the distribution of profits and losses in the organization through one's actions. Conflict resolution and negotiation advocates the position of a person with an open mind, does not personally consider the disagreements of other members, puts oneself in the shoes of others, follows rational arguments and avoids premature evaluation, and tries to synthesize the best ideas from all points of view and perspective [17]

Four components are considered to be the components most affected when learning online. Four of them are the ability of students to interact, the ability of students to communicate, the ability of students to work together, and the ability of students to empathize. Interaction is the process by which a person communicates to influence each other in thoughts and actions [18]. There area three important elements in communication namely the source of information, channel, and receiver of 
information. The source of information is a person or institution who has information material to be disseminated to the wider community. The channels used can be in the form of intrapersonal channels or mass media. Meanwhile, receivers of information are individuals or groups and people who are the target of information or who receive information [19]. Cooperation is a form of group wich consisting of more than someone who performs a task with several rules or procedures to achieve certain goals and mutual benefits must be achieved [20]. Empathy is the ability to identify and understand the feelings of others, take other people's points of view, and raise the emotional side of situations faced by others. [21].

Some applications of interpersonal skills in educational contexts are the relationship between teachers and students, students and students, and teachers and teachers. The interpersonal skills of students can develop when the teacher provides opportunities for students to use their potential with peers or with teachers who create mutually supportive relationships in learning [24]. So that the interpersonal skills of students can develop properly the learning process in the classroom should be able to make students able to develop interpersonal skills in themselves. Ways that can be done to develop students' interpersonal skills include: a) Forming a learning atmosphere that emphasizes cooperation among students; b) Grouping students randomly or according to certain criteria; c) Teaching students how to behave and play in a group and; d) Emphasis on common goals [25]. This shows that interpersonal skills can develop when the learning atmosphere is able to provide opportunities for students to discuss understanding the material. To develop students' interpersonal skills in learning, it can be done by working in groups, teach a friend whose score is insufficient, sharing opinions in groups, social interaction as a learning tool. [26].

Based on some of the opinions of the experts above, it can be concluded that interpersonal skills are the ability of students to interact, communicate, collaborate, see and consider other people's points of view, empathize with other students or teachers. Interpersonal skills are one of the most important determinants of success, so that this ability should not be neglected in the ongoing physical education learning process during the pandemic. In essence, the interpersonal skills of students must remain in the learning process, both face-to-face learning and online learning. In this study, the interpersonal abilities that will be observed are interaction, communication, cooperation and empathy in Physical Education learning.

\section{METHOD}

This study aimed to describe the interpersonal skills of students in learning physical education in grade IX of SMP Budi Utama Sleman in semester I of the 2020/2021 academic year during the pandemic. The population in this study were all students of grade IX. The method used in this research is descriptive. The variables in this study are interpersonal skills. In taking the sample, researchers used a proportional random sampling technique. The number of samples obtained in this study was 43 students, while the total population was 75 students.
In determining the number of samples, the researcher used the Taro Yamane or Slovin formula [27] which is as follows:

$$
\begin{aligned}
& n=\frac{N}{N \cdot d 2+1} \\
& n=\frac{75}{75.10 \%+1} \\
& n=\frac{75}{1,75} \\
& n=42,85
\end{aligned}
$$

So, the number of samples in this study was 43 students.

Explanation:

$$
\begin{array}{ll}
\mathrm{n} & : \text { sample size } \\
\mathrm{N} & : \text { population size } \\
\mathrm{d} & : \text { precision }
\end{array}
$$

(set at $10 \%$ with $95 \%$ confidence level)

In determining the distribution of samples to be fair it is determined by distributing all samples in each class, so that the distribution is as follows:

TABLE I. RESEARCH SAMPLE DISTRIBUTION

\begin{tabular}{|c|c|}
\hline Class & Total \\
\hline IX A & 15 \\
\hline IX B & 14 \\
\hline IX C & 14 \\
\hline Total & 43 \\
\hline
\end{tabular}

Data collection techniques in this study were questionnaires and interviews. The indicators in this study are seen from the ability of interaction, communication, cooperation and empathy which are important parts of the overall interpersonal skills component.

The questionnaire analysis of this study uses a Likert scale because the Likert scale is most often used in research with survey methods [28]. The interviews in this study used the Miles and Huberman model. Interviews were conducted orally by doing face-to-face in zoom aplication. In this case, an assessment guideline is needed before analyzing research data The questionnaire analysis steps are to give a score according to the following table:

TABLE II. QUESTIONNAIRE SCORING GUIDE

\begin{tabular}{|c|c|c|c|c|c|}
\hline \multirow{2}{*}{ Question } & \multicolumn{5}{|c|}{ Score } \\
\cline { 2 - 6 } & SL & SR & KD & JR & TP \\
\hline Positive & 5 & 4 & 3 & 2 & 1 \\
\hline Negative & 1 & 2 & 3 & 4 & 5 \\
\hline
\end{tabular}


Then, the scores obtained from filling out the questionnaire by students are then calculated using the percentage formula [29].

TABLE III. SCORE RANGE

\begin{tabular}{|c|c|}
\hline Score Range & Category \\
\hline $107<\mathrm{X}<114$ & Very high \\
\hline $99<\mathrm{X}<106$ & High \\
\hline $91<\mathrm{X}<98$ & Medium \\
\hline $83<\mathrm{X}<90$ & Low \\
\hline $75<\mathrm{X}<82$ & Very low \\
\hline
\end{tabular}

\section{RESULTS AND DISCUSSION}

The results of this study indicate the interpersonal skills of students as follows:

TABLE IV. SCORE RANGE

\begin{tabular}{|c|c|c|c|}
\hline Range & $\mathbf{F}$ & $\mathbf{( \% )}$ & Kategori \\
\hline $107<\mathrm{X}<114$ & 6 & 13,9 & Very high \\
\hline $99<\mathrm{X}<106$ & 8 & 18,6 & High \\
\hline $91<\mathrm{X}<98$ & 10 & 23,3 & Medium \\
\hline $83<\mathrm{X}<90$ & 12 & 27,9 & Low \\
\hline $75<\mathrm{X}<82$ & 7 & 16,3 & Very low \\
\hline Total & 43 & 100 & \\
\hline
\end{tabular}

In this study, the interpersonal abilities that were observed and studied were interaction, communication, cooperation and empathy. The following shows the data presentation of the average interpersonal skills of students seen from the dimensions of interaction, communication, cooperation and empathy of students taken from the results of filling out a questionnaire by participants in class IX SMP Budi Utama Sleman.

TABLE V. STUDENTS' INTERPERSONAL SKILLS

\begin{tabular}{|l|c|}
\hline \multicolumn{1}{|c|}{ Dimensions } & Percentage (\%) \\
\hline Interaction & 58 \\
\hline Communication & 69,8 \\
\hline Teamwork & 56,2 \\
\hline Empathy & 70,5 \\
\hline
\end{tabular}

Based on data in table 3, the average interpersonal ability of class IX students in Physical Education during the pandemic was $62.3 \%$. In this case, the average score obtained is 93.5 which this score is included in the interval $91<\mathrm{X}<98$ with the moderate category.

The results of the student interpersonal ability questionnaire showed that in the interaction aspect of students it was $58 \%$ or got an average score of 29 from a maximum value of 50.This shows that the interpersonal intelligence of students in the interaction dimension is in the medium category, meaning that students have made interaction good enough with friends and with the teacher, although not optimal.

In the communication dimension, the results obtained are $69.8 \%$ or get an average score of 27.9 from a maximum score of 40. This shows that the interpersonal skills of students in the communication dimension are in the moderate category. This means that students are good enough in understanding and communicating with friends and teachers through networkbased media in Physical Education learning, but communication skills still need to be improved

Cooperation between class IX students in the Physical Education subject is still in the moderate category, it is proven that the average interpersonal ability in this dimension only reaches $56.2 \%$ or gets an average score of 22.4 out of 40 . It can be interpreted that students experience problems. in collaborating with friends and teachers.

The empathy of class IX students in the Physical Education subject is still in the low category. From a maximum score of 20 students only get an average score of 14.1 or if a percentage is made, the dimension of empathy gets $70.5 \%$. This means that students do not yet have empathy for friends who have little score in Physical Education learning.

Overall, the interpersonal abilities of class IX students in Physical Education subjects during the pandemic were in the medium category. Based on the data obtained, there were 6 students in the very high category, 8 students in the high category, 10 students in the medium category and 12 students in the low category, and 7 students in the very low category. If the interpersonal ability score is in good category, the individual is not difficult to establish social relationships with other people [12]. In this case, students tend to prefer to do individual learning rather than having to follow group learning.

If the score of interpersonal skills is in low category, the individual is still difficult to establish social relationships with other people, in this case, social relations in the classroom during learning. who are solitary rather than having to be in groups, communication skills are still below average and still have difficulty dealing with problems that occur in their social relationships.

6 student have excellent interpersonal skills, or $13.9 \%$ in percentage. Based on the results of the interview, students who have high interpersonal skills tend to be more able to communicate well, whether it's communication with fellow students or with teachers. Happy to discuss because it can express opinions and discuss with each other about the subjects studied. High cooperation makes students in this category make them socialize with other friends. They also have empathy for other students by feeling that they are in the position of their friends who get small grades.

There were 10 students with moderate interpersonal skills, with a percentage of $23.3 \%$. Based on the results of interviews with students who are in the sufficient category, the researcher can conclude that they already have empathy for friends who get small grades in Physical Education, but they sometimes still care about themselves. They also like discussions related to learning with their friends, although sometimes it becomes uncontrollable because it will make them just playing. Students in this category tend to have the courage to ask questions, even though sometimes they feel afraid and embarrassed if they find an inappropriate moment. They are not picky about friends when carrying out lessons, discussions and group work. 
Students in sufficient category are already good at building social relationships [30].

7 student had very low interpersonal skills if the percentage was $16.3 \%$. Students in this category tend to have less desire to interact with their classmates, and even tend to be quieter. Communication of students in this category can also be said to only be done when there are important things, so that the intensity of communication with their friends is much rarer. Students in this category are also difficult to get to work with their groupmates, even if invited to discuss with the teacher. Students who have low interpersonal skills still have good enough empathy, they tend to understand the situation of their friends who have low Physical Education subjects.

\section{CONCLUSION}

Based on the results of the research and discussion above, it can be concluded that this study concluded that the interpersonal abilities of class IX students in the Physical Education subject during the pandemic were in the moderate category, meaning that students were still not optimal in interacting, communicating, cooperating, and their empathy level was still low during Physical education learning using distance learning. This shows that students have difficulties during Physical Education learning using distance learning. Researchers found that several student have very good category interpersonal skills. The findings of students who have good interpersonal skills should be followed up so that other students can have good interpersonal skills.

\section{REFERENCES}

[1] Cole, M. T., Shelley, D. J., \& Swartz, L. B. (2014). Online instruction, elearning, and student satisfaction: A three year study. International Review of Research in Open and Distance Learning, 15(6), 111-131. https://doi.org/10.19173/irrodl.v15i6.1748

[2] Nitko, A. J., \& Brookhart, S. M. (2014). Educational assessment of students pearson new international edition. London: Pearson

[3] Smaldino, S. E., Russell, J. D., Heinich, R., \& Molenda, M. (2019). Instructional technology and media for learning 12th Edition. In Revista mexicana de investigación educativa (Vol. 12). Scotland: Pearson

[4] Purnama Sari, D., \& Sutapa, P. (2020). Efektivitas Pembelajaran Jarak Jauh Daring Selama Pandemi Covid-19 Mata Pelajaran Pendidikan Jasmani Olahraga dan Kesehatan. Critical Care Medicine, 19-29. https://doi.org/10.1097/ccm.0000000000004475

[5] Charismiadji, Indra. (2020). Mengelola Pembelajaran Daring yang Efektif. Accessed from https://news.detik.com/kolom/d4960969/ mengelola-pembelajarandaring-yang-efektif

[6] Moma, L. (2015). Peningkatan Soft Skills Siswa Smp Melalui Pembelajaran Generatif. Jurnal Cakrawala Pendidikan, 2(2), 248-256. https://doi.org/10.21831/cp.v2i2.4829

[7] Agustini, Awang, I. S., \& Parida, L. (2019). Kemampuan interpersonal Peserta Didik Sekolah Dasar: VOX EDUKASI-Jurnal Ilmiah Ilmu Pendidikan. 10 , $120-128$. https://doi.org/https://dx.doi.org/10.31932/ve.v10i2.519

[8] Gardner, H. (2006). Multiple Intelligences. New York: Basic Group.

[9] Skillsyouneed. (2020). Accessed from https://www.skillsyouneed.com/ interpersonal-skills.html on Monday, 31 August 2020 at 19.35 WIB
[10] Onyema, E. M. (2020). Impact of Coronavirus Pandemic on Education. Journal of Education and Practice, 11(13), 108-121. https://doi.org/10.7176/jep/11-13-12

[11] Armstrong, Thomas. 2005.7 Kinds Of Smart. Menemukan dan Meningkatkan Kecerdasan Anda Berdasarkan Teori Multiple Intelligence. Jakarta:PT Gramedia Pustaka Utama

[12] Wulandari, Riswan Jaenudin, R. A. (2016). Analisis Kemampuan interpersonal Peserta Didik Pada Pembelajaran Ekonomi Di Kelas X Sma Negeri 2 Tanjung Raja. Jurnal Profit, 3 nomor 2, 183.

[13] Bedwell, W. L., \& Fiore, S. M. (2018). Developing the 21st Century (and Beyond) Workforce: A Review of Interpersonal Skills \& Measurement Strategies. 32826(407), 1-42.

[14] Talarico, J. F., Varon, A. J., Banks, S. E., Berger, J. S., Pivalizza, E. G., Medina-Rivera, G., Metro, D. G. (2013). Emotional intelligence and the relationship to resident performance: A multi-institutional study. Journal of Clinical Anesthesia, 25(3), 181-187. https://doi.org/10.1016/j.jclinane.2012.08.002

[15] Fatmawati, Endang. (2010). The Art of Library: Ikatan Esai Bergisi Tentang Seni Mengelola Perpustakaan. Semarang: Universitas Diponegoro.

[16] Budiningsih, Asri. 2005. Belajar dan Pembelajaran. Jakarta : Rineka Cipta

[17] Zhang, L. N. (2018). Importance of Interpersonal Skills at Work towards Managing People in an Educational Context. 54(Msmi), 29-34. https://doi.org/10.2991/msmi-18.2018.6

[18] Nur Rachma Permatasary, R. I. (2016). Interaksi Sosial Penari Bujangganong Pada Sale Creative Community. Journal of Educational Social Studies, 5(1), 15.

[19] Syam, Nina. 2012. Sosiologi sebagai Akar Ilmu Komunikasi. Bandung: Simbiosa Rekatama Media.

[20] Sarwono. S.W. 2011.Psikologi Remaja. PT Raja Grafindo Persada, Jakarta.

[21] Andayani, T. R., Studi, P., Fakultas, P., Sebelas, U., \& Surakarta, M. (2016). Studi Meta-analisis: Empati dan Bullying. Buletin Psikologi, 20(1-2), 36-51. https://doi.org/10.22146/bpsi.11947

[22] Widarto. (2011). Pengembangan Soft Skills: Mahasiswa Penddikan Vokasi Melalui Clop-Work (1st ed.). Yogyakarta: Paramita Publisher.

[23] Murat, K. (2015). Exploring the impact of sports participation on multiple intelligence development of high school female students. Educational Research and Reviews, 10(14), 2006-2011. https://doi.org/10.5897/err2015.2391

[24] Ummi, S. (2018). Efektivitas Model Project-Based Learning dan Model Problem-Based Learning Ditinjau Dari Prestasi Belajar, Kemampuan Komunikasi Matematis, dan Kemampuan Interpersonal Siswa Materi Statistika Dan Peluang Kelas VIII. Tesis, Universitas Negeri Yogyakarta, Yogyakarta.

[25] Gunawan, Adi W. (2007). Genius Learning Strategy. Jakarta: PT Gramedia Pustaka

[26] Alwi, Muhammad. (2014). Anak Cerdas Bahagia Dengan Pendidikan Positif. Jakarta: Noura Books

[27] Riduwan. (2013). Metode dan Teknik Menyusun Proposal Penelitian (Untuk Mahasiswa S1, S-2, dan S-3). Bandung: Alfabeta.

[28] Mulyatiningsih, Endang. (2011). Metode Penelitian Terapan Bidang Pendidikan. Yogyakarta: Alfabeta.

[29] Arikunto, Suharsimi. (2013). Manajemen Penelitian. Jakarta: Rineka Cipta.

[30] Safaria, Triantoro. (2005). Interpersonal Intlligence: Metode Pengembangan Kemampuan interpersonal Anak. Yogyakarta : Amara Books. 